\title{
Silencing Indigenous Knowledge Systems: Analysis of Canadian Educational, Legal and Administrative Practice
}

\author{
Liana B. Clarysse ${ }^{1} \&$ Shannon A. Moore ${ }^{2}$ \\ ${ }^{1}$ University of Toronto, Department of Curriculum, Teaching and Learning; Department of Comparative and \\ International Development Education, Graduate Studies at the Ontario Institute for Studies in Education \\ ${ }^{2}$ Director of Women's and Gender Studies, Associate Professor, Department of Child and Youth Studies, Brock \\ University \\ Correspondence: Shannon A. Moore. E-mail: smoore@brocku.ca
}

Received: February 11, 2019

Accepted: March 1, 2019

Online Published: March 20, 2019

doi:10.11114/ijlpa.v2i1.4157

URL: https://doi.org/10.11114/ijlpa.v2i1.4157

\begin{abstract}
As a result of the Truth and Reconciliation Commission of Canada (or TRCC, 2015a, 2015b), calls to action concerning education and law reform have been made. Currently, there is an increase in reconciliation discourse in law, healthcare and education policy, curricula and pedagogy. In Canada, efforts to decolonize institutional structures compel scholars and activists to highlight the imperative of critical analysis of identity and place in answering the calls to action. Although it was developed by the Ministry of Education for the province of Ontario, more than a decade ago, prior to the TRCC, the First Nations, Métis, and Inuit Education Policy Framework continues to inform policy and administrative procedures. Informed by Indigenous knowledge systems embedded in restorative justice and peace-building practices, this paper presents a critical analysis of the First Nations, Métis, and Inuit Education Policy Framework (2007) and finds evidence resembling discursive settler-colonial patterns of Indigenous erasure through the practice of silencing Indigenous participation and voice. Through this critical analysis, several themes emerged including colonialism, survivance, patriarchy, self-identification, notions of education, assessment, and "us versus them" binary narratives. In response, this paper argues for a trans-systemic and transdisciplinary approach to the critical analysis of discursive patterns of silencing and erasure in policy, law reform, and administrative processes. Further, through deepening interpretations and understandings of Indigenous theory and knowledge systems, it may be possible for settler-colonial stakeholders to more acutely discern the impact of settler-colonialism embedded in education, policy, administration, and legal discourses. These findings have implications for educators and administrators as well as administrative, law and policy reform.
\end{abstract}

Keywords: indigenous knowledge systems, restorative justice, truth and reconciliation commissions, trans-systemic policy analysis, transdisciplinary, education

\section{Introduction and Researchers' Positioning}

The authors of this paper are settler-educators and scholars with a range of practice-based experiences spanning two decades serving First Nations, Métis, Inuit and settler students in elementary, secondary and post-secondary classrooms. Any attempt to support the processes for decolonizing institutional structures requires a critical analysis of identity and place. As settler-educators and with guidance from the knowledge and lived experiences of Indigenous community members and scholars, our intention is to support the normalization of processes for decolonizing Canadian institutions. This can only be achieved by first, admitting the unearned privilege through exploitation from which we continue to benefit, contribute to and exist in complicity with settler-colonial hegemony. Any feeling or act towards decolonizing and any hope for subsequent reconciliation must, as a starting point and at the very least, involve an enduring and resilient commitment to reconciling these truths within ourselves.

A central challenge of this project is the act of supporting a just balance of two paradigms while enhancing the fortitude of new seeds of analysis and practice. As Battiste (2013) writes:

Bringing two diverse knowledge systems together needs some consideration of the assumptions underlying each 
foundation and where the points of inclusion or merging might seem advisable. The need then becomes one of developing "trans-systemic" analyses and methods — that is, reaching beyond the two distinct systems of knowledge to create fair and just educational systems and experiences so that all students can benefit from their education in multiple ways. Beyond suggesting that neither Indigenous knowledge nor Eurocentric knowledge systems can be the sole arbiter of the work involved, I am also suggesting that part of the ultimate struggle is a regeneration of new relationships among and between knowledge systems, which needs scholars competent in both knowledge systems to converge and reconcile these and other knowledges, ways of knowing, and systems. Such a practice has begun. (p. 123)

Battiste (2013) recommends a trans-systemic approach to analyzing education policy, curricula and pedagogy. A trans-systemic approach to analysis, involves the braiding of diverse knowledge systems to stabilize peace-building education that is socially just, accountable and tenable to a forward vision of the greatest potential for all students. This transdisciplinary approach is grounded in non-linear perspectives, complexity thinking and creative inquiry; it shares philosophical principles congruent with Indigenous knowledge systems which are propelling global reform movements in education (Moore, 2018). Education reform processes can be met, actualized and sustained through policies, curricula, pedagogies and instructional materials that are trans-systemic and transdisciplinary. Yet, for settler-scholars who engage in trans-systemic approaches to decolonizing education and administrative reform involving Indigenous knowledge systems (including research), critical reflexivity needs to be extended to settler-motive transparency and privilege (Styres, Haig-Brown, \& Blimkie, 2013). In law, policy and education reform (including research), motive transparency is critical to the decolonizing process and involves regenerative cycles of critical reflexivity and motive exploration (Styers et al., 2013).

Although a researcher does not have to be Indigenous to carry out Indigenous research (Wilson, 2013), as allies, settler-scholars' applications of Indigenous theories and paradigms must acknowledge privilege, cite Indigenous sources, and engage a reflexive process of meaning negotiation and interpretations (Battiste, 2013). Guided by transdisciplinary praxis (Moore, 2018) and Indigenous knowledge systems, the authors of this study engage a critical analysis to find evidence of themes resembling discursive settler-colonial patterns of Indigenous erasure through the practice of silencing. The themes that emerged were: colonialism, survivance, patriarchy, self-identification, notions of education, assessment, and "us versus them" binary narratives. Through deepening interpretations and understandings of Indigenous theory and knowledge systems, perhaps non-Indigenous stakeholders in education contexts may more acutely discern themes of settler-colonialism that are discursively embedded in discourses shaping our professional interventions. Traceable movement beyond tokenism resounds from decisions made by front-line educators and administrators. This involves micro and macro choices made in real time, a commitment to decolonization led by Indigenous voices, and a humble respect for the fact that these processes are never metaphorical or finished. Unfinished and evolving decolonizing processes include building toward or sowing seeds of trust that is not yet earned.

\section{Colonization and Colonialism}

Driven by imperialism (which is derived from the Latin word imperium, meaning supreme power) while actualized by, and dependent upon, the unequal distribution of the power Colonialism involves assimilation with intentions of colonization. Legitimated through rhetorical concepts such as adaptation and progress, colonization refers to the appropriation of land for economic and settlement purposes. Canada is a colonial nation that was established through the cultural genocide of First Nations, Métis and Inuit peoples who have (to quote the national anthem) inhabited this "home and native land" since time immemorial (Regan, 2010). Fueled by colonialism, a distorted sense of entitlement to colonize and the normalization of religious-based distortions and extremism, residential schools governed by the Indian Act of 1876 were instruments of violence (TRCC, 2015a, p. 1). Such that there is "not a single Indian in Canada that has not been absorbed into the body politic" (Duncan Campbell Scott, as cited in TRCC, 2015a, p. 6).

In Canada, for example, the Indian residential schooling system operated through destructive acts of settler-colonial violence. The "othering" of First Nations, Métis and Inuit peoples is evident in discourse that serves to legitimate and normalize acts of violence perpetrated through and concealed by the Canadian government and through the services offered by social systems (Al-Nakib, 2014; Bourdieu, 1986). Settler-colonialism of today reflects old habits, an insatiable desire for commercial gain, and antiquated but lingering social constructions (Lertzman \& Vredenburg, 2005). Characteristics of settler-colonialism may be present in aspects of the functioning and administration of education systems. Indigenous theorists speak of change through philosophical and pedagogical approaches (Cajete, 2000; Gorlewski \& Tuck, 2019; Maracle, 2017; Smith, 1999; St. Denis, 2011; Styres, 2008, 2017; Styres et al., 2013; Tuck, 2009; Tuck \& Ree, 2013; Tuck \& Yang, 2014).

Throughout the era of the Indian residential schooling system, the Canadian government sanctioned the forced removal of First Nations, Métis and Inuit children from their communities and families and their placement in residential schools. 
Installed from coast to coast, Canada's Indian residential schools were places where few children had positive experiences, and many endured the attempted erasure of personal and group identity through physical, spiritual, sexual, cultural and social violence (TRCC, 2015a, 2015b). Today, of the estimated 50 to 100 million non-Europeans who lived in pre-contact North America (Taylor, 2002; Mann, 2006, pp. 113-114; Stannard, 1992, pp. 51, 101, 267-268), only 5\% of the original, non-European inhabitants remain. Today, settler-colonial hegemony in a colonized "strong and free" country on "native land" (as the Canadian national anthem declares) relies on the denial of Indigenous nationhood (Snelgrove, Dhamoon, \& Corntassel, 2014; Regan, 2010; TRCC, 2015a, 2015b).

\section{Indigenous Knowledge Systems; Restorative Justice; Truth and Reconciliation}

Restorative Justice has ancient roots found in Indigenous knowledge systems around the globe (Clarysse \& Moore, 2017; Moore \& Clarysse, 2018), systems that have contemporaneously influenced discourses across psychology, education, sociology, peace studies, philosophy and law (Cremin, Sellman, \& McCluskey, 2012; Morris, 2002). Restorative justice and restorative practices in judicial and educational contexts have been shown to divert harmful behaviour and criminal acts. In addition, restorative justice offers diversified relevance in modes of implementation and there is evidence that restorative justice has an impact on relationships (Cremin et al., 2012; Morris, 2002). Dialogical and relational components of restorative justice are multifaceted and may include interactions that occur face to face (facilitative) or via a shuttled meditator. Restorative justice can improve relationships or simply clarify the logistics of steering clear of each other (Cremin et al., 2012; Morris, 2002). According to Carruthers (2010), the Children, Young Persons and their Families Act (New Zealand, 1989 ) returned traditional Ma ori restorative approaches to resolving conflict in New Zealand's (youth) justice system. After much success at diverting youth from criminal acts, restorative justice was reinstated in New Zealand's adult criminal court system despite intense political pressure to the contrary. Subsequently, restorative theory was applied to discipline practices in the New Zealand school system (Carruthers, 2010, as cited in Cremin et al., 2012 ).

Restorative justice, restorative practices and truth and reconciliation processes are globally significant and contemporarily relevant (Moore, 2017; Gabe, 2013) yet situated within ancient and contemporary cultures in more than 100 countries, including Canada, the United States, and the United Kingdom (Clarysse \& Moore, 2017; Moore, 2003, 2007, 2017). The same principles that inform present-day restorative justice processes also shape truth and reconciliation processes around the globe, including examples from South Africa and Canada. Restorative justice and restorative practices have addressed harm, held offenders accountable, fortified rehabilitation and served as catalysts for healing and closure in legal and education systems in Canada and the United Kingdom for more than a century (Clarysse \& Moore, 2017; Moore, 2003, 2007, 2017). Sharing tenets with restorative justice, truth and reconciliation commissions are informed by Indigenous governance practices and knowledge systems. Universally, truth and reconciliation processes have served as starting points from which settler-colonial acts towards accepting responsibility for the cultural genocide of Indigenous peoples unfold (i.e., Africa in 1999 and Canada in 2015). In Canada, cultural genocide was carried out, in part, through the education system, resulting in the Truth and Reconciliation Commission of Canada (2015a, 2015b) calls to action specifically related to education (see p. 7 ).

Truth and Reconciliation and the Indian Residential Schooling System in Canada (1863-1996)

"Education has gotten us into this mess, and education will get us out"

Senator Murray Sinclair, Chair of Canada's Truth and Reconciliation Commission (as cited in Anderson, 2016, p. 1).

Colonialism is reflected in social systems, and likewise, education systems are a reflection of a nation's articulation of values. The government-mandated Indian residential schooling system of Canada is an example of the misuse of education as an instrument of settler-colonial violence (TRCC, 2015a, 2015b). Beyond metaphor or symbolism, Calls to Action in the TRCC (see p. 7, calls to action \#62 \& \#63, 2015a) address reconciliation through education and emphasize the need for policy to be developed and translated into action in a manner that is relevant and accountable. Yet, if traceable steps are not taken to answer the Calls to Action, they remain merely words on a page identified by numbers. But what is the significance of numbering? Historically, governmental processes of objectification through the systematic practice of assigning numbers to peoples, laws and policies have served agendas of homogenization. Assigning a number to a distinct Call to Action that generates inaction may be perceived as a continuation of cultural objectification and homogenization.

\section{Janus Face of Education}

The notion of a Janus face refers to the quality of having two distinct, and often diametrically opposed characters, originating and operating from the same location. According to Bush and Saltarelli (2000), the Janus face of education refers to elements of schooling (such as curriculum and pedagogy) that may be instruments of either peace or violence. Discourse in curricula, policy, textbooks and instructional materials have the potential to influence the distribution of 
power. Systematic cultural assimilation may be legitimated by implicit and explicit standards, in national and provincial policy, curricula, textbooks and instructional materials. Tracing and critically analyzing what is said or unsaid within curricula, legal and policy texts may lead to sources of settler-colonial violence. Thus leaving settler-colonial hegemonic discourse in curricula, policy, law and instructional materials undisrupted may be an act of oppression, cultural deprecation and exclusion through habitual normalizing and rationalizing practices. Settler-colonial hegemony in education discourses serve to disrupt cultural continuity and generational knowledge sharing which has a profound impact on Indigenous students, for example with respect to discrepancies in rates of attrition between Indigenous and settler students (St. Denis, 2011; Tupper, 2011; Godlewska et al., 2017).

According to Apple $(1979,1990)$, hegemony reflects the economic goals, cultural power distribution and ideology among pods of sociopolitical dominance. In educational contexts, hegemonic discourses operate in several ways including the allocation of privilege, gaze and a listening ear to certain people and perspectives (Apple, 1979, 1990). Giroux (1981) indicates that the unconscious facets of hegemony are elucidated through mutual consent to domination via ideological indoctrination and systemic biases that are falsely validated and subsequently renewed. For instance, Cajete (2000) describes the silencing impact of criollo hegemonic exclusion through the experiences of the Indigenous peoples of the Andes. Indigenous people of the Andes experience forced indoctrination and social reproduction practices (e.g., language silencing). Policy, curricula, laws, pedagogy and instructional materials have the potential to become instruments of violence that reconvene with the start of every new semester (Davies, 2014). Curricula, policy, law, pedagogy and instructional materials are shaped by the spoken and unspoken word of those who hold power and leadership roles. What goes unsaid indicates potential for the unknown.

\section{Janus Face Of Education: Global Glance}

Eisner (1994) argues that schools have consequences which are shaped equally by what is and is not taught and this theory may be relevant in a variety of educational contexts and diverse regions of the world. In Canadian educational contexts, settler-colonialism is enacted through both implicit and explicit provincial curricula, pedagogies and instructional materials.

Implicit curriculum is embedded within cultural norms that inform laws, policies, pedagogies and dialogue (including tone and silences) and reinforcement (positive or negative) (Bickmore, 2011; Bush \& Saltarelli, 2000; Williams, 2004; Giroux, 1981) while explicit curriculum includes lesson plans and lists of rules (Bickmore, 2011; Bush \& Saltarelli, 2000. The impact of implicit curriculum is evident in a study of Trinidadian teachers where Williams (2017) writes about teachers' authentic use of student language as a mode for humanizing curriculum and pedagogy. In the Cuzco region of Peru, teachers are not simply servants of the public. Instead, teachers are vehicles delivering settler-colonial indoctrination (Garcia, 2005, as cited in Regalsky \& Laurie, 2007). To explain, adhering to a settler-colonial agenda, teachers guarantee early access to students during their formative years and expose them to an implicit curriculum that engages practices of othering, homogenization and legitimation of the agenda for settler-colonialism. In another example of implicit curriculum, a critical analysis of science textbooks from Kaomea (2005) points out that "savagery" narratives validate settler-colonialism with the example of legitimating genocide (100 years after contact, Indigenous peoples of Hawaii were decimated, with a population reduction from 800,000 to 40,000) resulting from European colonization, but also blaming the Indigenous peoples of Hawaii through a discourse that normalizes genocide. In the Quechuan communities of Raqaypampa Cochabamba, Bolivia, Criollo hegemony expressed both implicitly and explicitly is evident in schools seeking to invalidate and dissolve Indigenous cultures through culturally reproductive practices in schools (Regalsky \& Laurie, 2007). In a similar way, implicit and explicit curriculum delivered settler colonial rhetoric (i.e., saving the savage) which served to justify violence towards First Nations, Métis and Inuit children and youth including Canada's Indian residential schooling system.

In addition to implicit (hidden) and explicit curriculum, Eisner (1994) refers to that which is not taught whatsoever as null curriculum. The null curriculum encompasses what is not learned by students and includes what students neither have access to nor are aware of. Examples of the null curriculum include non-verbal communication and modes of thought that are what Chaka, Lephalala, and Ngesi (2017) refer to as "alogical" (p. 214).

Awareness of the trajectories of complex power relations and recurring habits of subject formation are traceable in the implicit curriculum. Awareness of hegemony in policy and pedagogy may heighten sensitivity to structural and systemic bias. For example, tracking settler-colonial practices of problematizing Indigeneity while simultaneously skimming over the depth and relevance of Indigenous knowledge systems locates power relations and the preferred direction of a common hegemonic narrative (Styres et al., 2013). The insidious normalization of hegemonic discourse in education law, policy, curriculum and pedagogy rationalizes marginalization, oppression, deprecation and exclusion. 


\section{Silence}

In a noisy world, silence is powerful. Dialogical exchanges of silence or sound express relations of power and identity. The distribution of power often inhabits silences within the discourse and delivery of law, policy, curriculum and pedagogy (Schulz, Ainley, Fraillon, Kerr, \& Losito, 2010; Styres, 2008). In settler colonial processes of colonization, language and land are treated in the same manner. Land is taken over by the colonizer while the language of the colonized is silenced by the language of the colonizer. In these instances, language and land are subjugated and subdued (Styres et al., 2013). Likewise, in an education system founded on Eurocentric patriarchy, the disempowerment of marginalized students through silencing is polymorphic and the cumulative impact of silencing on marginalized voices is that of slow violence (Nixon, 2011).

For the marginalized, the silence generated by what is absent from policy, curricula, pedagogies and classroom discussions widens knowledge gaps that are often filled with hegemonic ideologies. Yet, policy and education-related discourses have the potential to decolonize. The silence of what is absent from policy, curricula and pedagogy can colonize, decolonize, construct or deconstruct power dynamics (Styres, 2008; Styres et al., 2013). In an education system based on Eurocentric patriarchy, the disempowerment of marginalized students through the silencing of their desires, vision or voice is not uncommon. According to Battiste (2013), education that decolonizes respects diversity and pluralism through dialogical pedagogies.

Oppressive silence is an attack on what Styres (2008) and colleagues (Styres et al., 2013) refers to as the learner's "embodied knowledge base" (Nixon, 2011). Transformative silences inhabiting liberating spaces impact the lived experiences of marginalized students. The presence of silence within dominant narratives of policy, curriculum and pedagogy may be a powerful construct. The presence or absence of silence may intensify or disengage misconceptions. In the face of denigration and imbalances of power and privilege, there is dignity in silence. As such, silence can be a mode of resistance to oppression and an expression of self-determination.

\section{Thematic Analysis: FNMI Education Policy Framework (2007)}

For the purpose of this study, our document analysis will focus on the First Nation, Métis, and Inuit (FNMI) Education Policy Framework ( Province of Ontario, 2007). The First Nation, Métis, and Inuit Education Policy Framework serves as a basis from which all curriculum design may be informed for Ontario. Through critical analysis of this document, several themes emerged: colonialism, survivance, patriarchy, self-identification, notions of education, measurement/assessment, us/them narratives yet "shared responsibility" and legitimation.

\subsection{Colonialism}

The introduction of the Education Policy Framework for the province of Ontario cites a lack of understanding of First Nations, Métis and Inuit learning styles, cultures, history and perspectives on the part of teachers, schools and school boards as the reason for the disparity between First Nations, Métis and Inuit and settler students in several dimensions: numeracy scores; rates of school retention; graduation; and advancement to postsecondary studies (p. 6). However, at no time is there mention of settler-colonial acts of subjugation and colonialism (Smith, 1999).

The Ministry articulates a commitment to supporting First Nations, Métis and Inuit students (p. 7) yet does not mention the pervasiveness of settler-colonialism. Instead, the Education Policy Framework points to educators' "lack of awareness" (p. 6) as a key reason for disparity among First Nations, Métis and Inuit students and their settler peers. The notion of lacking awareness risks a self-congratulatory tone of feigned naivety through the assumption that with access to the right information, people will do what is right (Tuck \& Ree, 2013; Tuck \& Yang, 2014). Moreover, Regan (2010) cautions against the potential for reconciliation ideology and discourse to absolve from commitments to treaty agreements and acting in good faith. Questioning the sincerity of reconciliation initiatives, Regan (2010) suggests that it may be difficult to perceive reconciliation as little more than a superficial gesture. Boiling down the disparity between Indigenous and settler students to a lack of understanding, with no mention of the impact of Eurocentric influences in the education system, potentially undermines the reconciliatory merit of the policy framework.

\subsection{Survivance}

The First Nations, Métis and Inuit Education Policy Framework refers the capability of the Ontario Ministry of Education and school boards to elevate the confidence, and offer knowledge and skills of First Nations, Métis and Inuit students (p. 7). However, no attention is given to the survivance that is rooted in their inherent confidence, traditional knowledge, and skills. As a celebration of survival, survivance is facing oppression with both survival and resistance (Vizenor, 2008; Smith, 1999). Bloch (2009) cautions against deeming education the cause and antidote for broader social and economic inequities. Moreover, in a study of students in South Africa, factors that impact confidence, knowledge and skills include: intergenerational social disadvantage; the role of teachers' poor subject knowledge; 
teaching practices; an inadequate numbers of teachers; lack of teacher performance evaluations; dysfunctional and poorly managed schools; a continuing lack of such basic resources as libraries and computers; poverty including malnutrition and HIV/AIDS; gangs; drugs; and a lack of support for schools at provincial and district levels. While the Ontario Ministry of Education indicates the capability to impact the confidence, knowledge and skills of First Nations, Métis and Inuit students discourse on the perpetuation of inequity in education systems is absent, perhaps steering learning towards the teachings offered through the intimate relationship between First Nations, Métis and Inuit survivance and self-determination may be more relevant to the vision of this framework, which states that: "All students in Ontario will have knowledge and appreciation of contemporary and traditional First Nation, Métis, and Inuit traditions, cultures, and perspectives" (Ontario First Nation, Métis, and Inuit Education Policy Framework, 2007, p. 7).

\subsection{Patriarchy}

According to Smith (1999), patriarchy is a form of ethnocentric domination over Indigenous peoples. Examples of the Ontario First Nation, Métis, and Inuit Education Policy Framework continuously referring to the "progress", "needs" and "helping" of First Nations, Métis and Inuit students will be explored below in a manner that connects with a patriarchal tone.

On page 13 of the Policy Framework, "progress" is only possible through the monitoring, inscribing or harvesting of information from First Nations, Métis and Inuit students and their families. This prerequisite for progress silences the importance of ceremony, participation and tradition involving peoples and places of importance to First Nations, Métis and Inuit students as meaningful reflections and celebrations of progress (Tuck \& Gorlewski, 2016). There is mention of reporting the progress of Indigenous students to their families and communities (p. 13), which may hint to interconnectedness and the importance of family and community in Indigenous learning traditions and theories. Settler-colonial ideals of progress imply linear stages of development that potentially ascribe a state of infancy to First Nations, Métis and Inuit students. Indigenous scholars (Smith, 1999) have found this way of relating history particularly problematic, calling into question the appropriateness of applying a similar discourse to the First Nations, Métis and Inuit Education Policy Framework for the province of Ontario.

Beginning on page 7, the Policy Framework refers to the "needs" of First Nation, Métis, and Inuit students, which implies a state of infancy or incompletion. Thus, misconceptions of the "need" to be rescued by those who, in a patriarchal tone, deem themselves more capable are fortified by discourse that has potential for implications of infancy and inadequacy. Throughout the First Nations, Métis and Inuit Education Policy Framework, use of the word "needs" in reference to the requirements of First Nations, Métis and Inuit students is very pronounced (pp. 5-8, 11, 12-16, 20, 21, 24-26, 28-30). A suggested recalibration of education discourse from a place of need or implied deficiency to the articulated hopes, desires and thriving vision and of First Nations, Métis and Inuit students may be more relevant and validating of Indigenous self-determination (Smith, 1999; Tuck, 2009).

The Ministry document refers to their capabilities for "helping" First Nations, Métis and Inuit students to succeed. What may be relevant is an "action plan" (pp. 14, 15, 21) of how the Ministry will work towards dismantling systemic barriers that leave First Nations, Métis and Inuit students few choices beyond circumventing success (p. 18). In addition, notions of "helping" suggest roles of vulnerability and expertise which may be interpreted as patronizing and self-congratulatory (Smith, 1999). Indigenous sovereignty is indiscernible behind clouds of deficit-oriented discourse. Referring instead to decolonizing education as a process of honouring Indigenous knowledge systems, hopes and visions for the future may be one way to distance policy texts and practice from deficit rhetoric (Tuck, 2009).

\subsection{Self-Identification}

After referencing the Policy Framework as a starting point (p. 9), the Ministry of Education requires First Nations, Métis and Inuit students to engage in a process of self-identification (p. 10). Globally, the history of Indigenous identity politics (i.e., blood quantum theories) as well as the manner in which the Indian Act of Canada (1876) attempted to eradicate Indigenous nationhood justifies potential apprehensions within self-identification protocols. Racializing politics have been largely driven by belief systems that are racist (St. Denis 2002, 2007, as cited in Battiste, 2013). On page 10, self-identification is indicated as the "basis" for "gathering relevant First Nations, Métis and Inuit student information" yet, what may be missing here is the distinction between practices of self-identification and practices of surveillance. With regard to behaviour management, surveillance approaches to mitigating violence in educational institutions are often punitive in ethos and relationally destructive. Prioritizing a goal of social control and surveillance may only serve to erode relationships (Bickmore, 2011; Gonzalez, 2012) and undermine the intention of the First Nation, Métis and Inuit Education Policy Framework to "foster good relationships" (p. 26).

\subsection{Constructions of Education}

Holistic learning is mentioned in the First Nation, Métis and Inuit Education Policy Framework on page 6. Holism in 
and among traditional Indigenous education theories is explained by Morcom (2017) as follows:

Holism intercalates every aspect of Anishinaabe and many other Indigenous epistemologies, including one's understanding of the self and one's relationship to the community, other living things, the earth, and the divine. This orientation has a significant impact on pedagogy and classroom practice. It also determines how curriculum is understood and utilized from an Indigenous perspective; in stark contrast to the compartmentalization of subjects in the Western education system, Indigenous educational philosophy focuses on interrelationships between different subjects. This perspective is central to Indigenous sense-making. While the fundamental assertions of Western and Indigenous educational philosophies are significantly different, it is possible to meet Western curriculum expectations through Indigenous pedagogy by enacting holistic teaching practices and focusing on topics and interrelations. (p. 121)

Although holistic learning is mentioned in the First Nation, Métis and Inuit Education Policy Framework (p. 6), the subsequent requisition to track and measure the success of First Nations, Métis and Inuit students in compartmentalized subject areas runs counter to a holistic approach (p.10). Unidirectional strides towards goals in disconnected subjects may be incongruous with Indigenous educational philosophies of Holism (Styres, 2017; Smith, 1999).

In the Education Policy Framework, the Ministry of Education highlights the need for teachers' professional development as well as relevant assessment tools for supporting the "learning styles" of First Nations, Métis and Inuit students (p. 12). However, compartmentalizing learning styles reflects Eurocentric constructions of education and, once again, contrasts directly with interconnectedness in education. Battiste (2013) describes Indigenous knowledge systems as: "rich resources for the world's humanities" that "can, like the humanities emerging from Eurocentric philosophy so long ago, be a source of inspiration in a new time and in an old place" ( p. 182).

Yet, in the First Nation, Métis and Inuit Education Policy Framework (2007) there is no mention of complex Indigenous ways of knowing and being in the world that are ancient yet simultaneously relevant and applicable to contemporary education (pp. 10,11, 12, 21).

\subsection{Measurement/Assessment}

In the First Nation, Métis and Inuit Education Policy Framework, there are indications of standardized assessments. Yet, the connections between standardized assessment and the colonial notion of empowerment have historically relied upon the unequal distribution of power (Styres, 2017; Tuck \& Gorlewski, 2016). The word "power" in reference to First Nations, Métis and Inuit students is absent while "power" is mentioned twice in reference to the power of Band Councils and the power of the Government of Canada (pp. 36, 38). On page 14, a measure of success in the implementation of the First Nation, Métis and Inuit Education Policy Framework will be the improvement to the self-esteem of First Nations, Métis and Inuit students. However, there is no mention of the impact of colonialism, racism and standardized testing on the self-esteem of First Nations, Métis and Inuit students (Battiste, 2013).

\subsection{Us/Them Narratives Yet "Shared" Responsibility}

The goal to ameliorate "public confidence" is indicated on page 17 of the First Nation, Métis and Inuit Education Policy Framework. Yet, absent in the document are the potential reasons why the First Nations, Métis and Inuit students and their communities may have a sense of distrust for the "public" (Battiste, 2013). There is use of the term "action plan" on pages 14, 15 and 21 of the First Nation, Métis and Inuit Education Policy Framework. However, nowhere in the framework is the act of listening mentioned. Styres (2017) indicates that storying (including listening) is an essential part of building trust in many Indigenous cultures. The word "story" is found twice in the Policy Framework (pp. 28, 38) but only as part of the word "history". This leaves the reader to question whose story is prioritized in this document although the title implies its development specifically for First Nations, Métis and Inuit peoples.

The First Nations, Métis and Inuit Education Policy Framework names a "public" that exists apart from First Nations, Métis and Inuit peoples while simultaneously homogenizing them in a discourse that may be interpreted as marginalizing and divisive. For example, the Policy Framework differentiates the responsibilities of the "public" (p. 17) with notions of "shared responsibility" (p. 8). This leaves the reader with the unanswered question of "responsibility for what?" In light of the Truth and Reconciliation Commission of Canada (2015b), an undefined indication of "shared responsibility" may be interpreted as a form of blame or deflection (Maracle, 2017). The replacement of discursive evasiveness in place of the taking of responsibility with indicators of a "blame game" may run counter to the stated goal of the Policy Framework.

\section{Discussion and Conclusion}

As articulated by Bickmore, Hayhoe, Manion, Mundy, and Read (2017): 
time has come for humanity to adopt new ways of learning that will prepare us for a sustainable global future, and that we need to look toward an Aboriginal, holistic education model to lead the way toward the establishment of world peace. (p. 171)

Globally, the hand of hegemony in laws, policies and official documents has far-reaching implications. For example, the Indian Act of 1876 legitimized the establishment of the Indian residential schools system in Canada and enforced the removal of First Nations, Métis and Inuit children from their families and communities (TRCC, 2015a, 2015b; Coates, 2008). The Truth and Reconciliation Commission of Canada (2015a, 2015b) calls for changes in the education system that may support decolonization and reconciliation. In order for education law, policy, curriculum and pedagogy to be relevant to the lives of all students, reform must be inclusive of students' lived, as well as ancestral, traditions and experiences.

Through Pueblo metaphors, Cajete (2000) describes a vision of an education system based on Indigenous philosophies because of their relevance and responsiveness to the growing needs of contemporary education. Cajete (2000) suggests looking "to the mountain" as a metaphor for gazing towards the highest perspective in all teachable moments in life. Cajete further encourages us to examine our relationship with life through a "native eye" in order to "look more deeply" and draw strength and wisdom from the teachable moments of which we are gifted through life experiences (p. 182). Guided by Indigenous scholarly theory to "look more deeply" and, (as invited by Cajete, 2000) with a "native eye" (p. 182), the authors of the critical analysis of the First Nations, Métis and Inuit Education Policy Framework for the province of Ontario, Canada (2007), found thematic evidence of discursive settler-colonial patterns of Indigenous erasure through what is absent or silenced. Findings highlighted several themes including: colonialism, survivance, patriarchy, self-identification, notions of education, assessment and us versus them (yet shared responsibility) narratives. These findings suggest that a trans-systemic analysis (Battiste, 2013) may support decolonization in law, policy and the reform of official documents. Pre-service and professional development led by Indigenous educators may engage settler acuity to hegemonic themes of colonialism that are discursively embedded or silenced in laws, policies and official documents and, thus, actualize the decolonizing potential of critical peace building education (Bickmore et al., 2017). To close, we return to Cajete (2000) and highlight clarion calls for a close examination of old habits. Perhaps the excavating of old habits will reveal the archeology of change. Through guidance from Indigenous peoples including future studies exploring themes of colonialism, survivance, patriarchy, self-identification, notions of education, assessment, and "us versus them" binary narratives, settler-allies may begin to re-centre Indigenous knowledge systems in education law, policy, curriculum and pedagogy. For example, a recalibration of discourse from a place of need or implied deficiency to the articulated hopes, desires and thriving vision and of First Nations, Métis and Inuit students may be more relevant and validating of Indigenous self-determination (Smith, 1999, 2012; Tuck, 2009).

\section{References}

Al-Nakib, R. (2014). Dialogic universalism and human rights education: a case study from Kuwait. Compare: A Journal of Comparative and International Education, 44(3), 495. https://doi.org/10.1080/03057925.2013.821311

Anderson, S. (2016, June 9). Murray Sinclair: Education is the key to reconciliation. Rabble.ca.

Apple, M. (1979). Ideology and curriculum. London: Routledge.

Apple, M. (1990). Ideology and curriculum. London: Routledge.

Battiste, M. (2013). Decolonizing education: Nourishing the learning spirit. Saskatoon, SK: Prich Publishing.

Bickmore, K. (2011). Policies and programming for safer schools: Are "anti-bullying" approaches impeding education for peacebuilding? Educational Policy, 25(4), 648-687

Bickmore, K., Hayhoe, R., Manion, C., Mundy, K., \& Read, R. (2017). Comparative and international education: Issues for teachers (2nd ed.). Toronto: Canadian Scholars Press Inc.

Bloch, G. (2009). The education roadmap: Taking education forward. Report to Parliament: Portfolio Committee on Higher Education and Training, August 19, 2009. Retrieved March 26, 2010, from http://www.pmg.org.za/files/docs/090819Roadmap.doc

Bourdieu, P. (1986). The forms of capital. In J. Richardson (Ed.), Handbook of theory and research for the sociology of education (pp. 241-258). New York: Greenwood Press.

Bush, K., \& Saltarelli, D. (2000). The two faces of education in ethnic conflict: Towards a peacebuilding education for children. Florence, IT: UNICEF Innocenti

Cajete, G. (2000). Indigenous knowledge: The Pueblo metaphor of indigenous education. In M. Battiste (Ed.), Reclaiming indigenous voice and vision (pp. 181-191). Vancouver, BC: University of British Columbia Press. 
Carruthers, D. (2010). Utilising restorative justice practices in school disciplinary procedures (the journey from criminal justice to education). Paper presented as part of the Restorative Approaches to Conflict in Schools seminar series, London, February. Retrieved from http://www.educ.cam.ac.uk/research/projects/ restorativeapproaches/seminarone/

Chaka, C., Lephalala, M., \& Ngesi, N. (2017). English studies: Decolonisation, deparochialising knowledge and the null $\begin{array}{lllll}\text { curriculum. } & \text { Perspectives } & \text { Education, }\end{array}$ http://dx.doi.org.myaccess.library.utoronto.ca/10.18820/2519593X/pie.v35i2.16

Clarysse, L. B., \& Moore, S. A. (2017). Restorative justice, peacebuilding practices, and educational praxis: Critical analysis of Canadian and United Kingdom discourses. Journal of Leadership, Accountability and Ethics, 14, 123138.

Coates, K. (2008). The Indian Act and the future of aboriginal governance in Canada. Ottawa, ON: National Centre for First Nations Governance. Retrieved from http:// fngovernance.org/ncfng_research/coates.pdf

Cremin, H., Sellman, E., \& McCluskey, G. (2012). Interdisciplinary perspectives on restorative justice: Developing insights for education. British Journal of Educational Studies, 60(4), 421-437. https://doi.org/10.1080/00071005.2012.738290

Eisner, E. W. (1994). The educational imagination: On the design and evaluation of school programs. New York: MacMillan College Publishing Company

Gabe, C. (2013). Restorative justice and the South African truth and reconciliation process. South African Journal of Philosophy, 32, 10-35. https://doi.org/10.1080/02580136.2013.810412

Giroux, H. (1981). Pedagogy, pessimism, and the politics of conformity: a reply to Linda

McNeil. Curriculum Inquiry, 11(3),211-22

Godlewska, A., Schaefli, L., Massey, J., Freake, S., Adjei, J. K., Rose, J., \& Hudson, C. (2017). What do first-year university students in Newfoundland and Labrador know about Aboriginal peoples and topics? The Canadian Geographer / Le Géographe canadien, 61(4), 579-594. https://doi.org/10.1111/cag.12428

González, T. (2012). Keeping kids in schools: Restorative justice, punitive discipline, and the school to prison pipeline. Journal Of Law \& Education, 41(2), 281-335.

Gorlewski, J., \& Tuck, E. (Eds.). (2019). Who decides who becomes a teacher? New York: Routledge

Kaomea, J. (2005). Indigenous studies in the elementary curriculum: A cautionary Hawaiian example. Anthropology \& Education Quarterly, 36, 24-42. https://doi.org/10.1525/aeq.2005.36.1.024

Lertzman, D. A., \& Vredenburg, H. (2005). Indigenous peoples, resource extraction and sustainable development. Journal of Business Ethics, 56(3), 239-254.

Mann, C. (2006). 1491: New revelations of the Americas before Columbus (pp.113-114). New York: Vintage Books.

Maracle, L. (2017). My conversations with Canadians. Toronto: BookThug. ISBN 978-1-77166-358.

Ministry of Education. (2007). Ontario First Nation, Métis and Inuit Education policy frame work. Toronto, ON: Queen's Printer for Ontario.

Moore, S. A. (2003). Towards an integral transformation: Through the looking glass of restorative justice (Unpublished doctoral dissertation). University of Victoria, Victoria, BC.

Moore, S. A. (2007). Restorative justice. In R. B. Howe \& K. Covell (Eds.), A question of commitment: Children's rights in Canada (pp. 179-208). Waterloo, ON: Wilfrid Laurier University.

Moore, S. A. (2017). Restorative justice education, policy \& practice: Transdisciplinary reflections on mental health implications. In J. Evans (Ed.), Restorative and transitional justice: Perspectives, progress and considerations for the future (pp. 1-24). New York: Nova Science Publishers, Inc.

Moore, S. A. (2018). Radical listening: Transdisciplinary, restorative justice and Change. World Futures: The Journal of New Paradigm Research, 74(7-8), 471-489.

Moore, S. A., \& Clarysse, L. B. (2018). Truth, reconciliation, restorative justice, and Canadian discourses of legitimation in educational contexts. Special issue on international law. Beijing Law Review, 9(4), 481-498. 
Morris, A. (2002). Critiquing the critics: a brief response to critics of restorative justice. British Journal of Criminology, 42(3), 596-615.

Morcom, L. (2017). Indigenous Holistic Education in Philosophy and Practice, with Wampum as a Case Study. Foro de Educación, 15, 121-138. https://doi.org/10.14516/fde.572

New Zealand: Children, Young Persons, and Their Families Act 1989 [], 1 November 1989, available at: https://www.refworld.org/docid/3ae6b5d10.html [accessed 9 February 2019]

Nixon, R. (2011). Slow violence and the environmentalism of the poor. Revista Critica De Ciências Sociais, 2013(100), 235-237. Retrieved from http://myaccess.library.utoronto.ca/login?url=https://search-proquest-com.myaccess.library.utoronto.ca/docview/20 74201415 ?accountid $=14771$

Regalsky, P., \& Laurie, N. (2007). The school. Whose place is this anyway? Indigenous Education in Bolivia. Comparative Education, 43(2), 231-251.

Regan, P. (2010). Rethinking reconciliation: Truthtelling, restorying history, commemoration. In P. Regan, Unsettling the settler within: Indian residential schools, truth telling, and reconciliation in Canada (pp 54-82). Vancouver, BC: UBC Press.

Schulz, W., Ainley, J., Fraillon, J., Kerr, D., \& Losito, B. (2010). ICCS 2009 international report: Civic knowledge, attitudes and engagement among lower secondary school students in thirty-eight countries. Amsterdam: International Association for the Evaluation of Educational Achievement.

Sherman, L. \& Strang, H. (2007) Restorative Justice: The Evidence, London, Smith Institute.

Smith, L. T. (1999). Decolonizing methodologies: Research and indigenous peoples. London: Zed Books.

Snelgrove, C., Dhamoon, R. K., \& Corntassel, J. (2014). Unsettling settler colonialism: The discourse and politics of settlers, and solidarity with indigenous nations. Decolonization: Indigeneity, Education \& Society, 3(2), 1-32.

St. Denis, V. (2011). Silencing aboriginal curricular content and perspectives through multiculturalism: "There Are Other Children Here". Review of Education, Pedagogy, and Cultural Studies, 33(4), 306-317. https://doi.org/10.1080/10714413.2011.597638

Stannard, D. (1992). American holocaust: The conquest of the new world (pp. 51, 101, 267-268). New York. Oxford University Press.

Styres, S. (2008). The silent monologue: The voice within the space. AlterNative Journal: An International Journal of Indigenous Peoples, 4(2), 89-101.

Styres, S. (2017). Pathways for remembering and recognizing indigenous thought in education: Philosophies of Iethi'nihsténha Ohwentsia 'kékha (land).Toronto: University of Toronto Press.

Styres, S., Haig-Brown, C., \& Blimkie, M. (2013). Toward a pedagogy of land: The urban context. Canadian Journal of Education/Revue canadienne de l'éducation, 36(2), 188-221.

Taylor, A. (2002). American colonies: The settling of North America. New York: Viking Penguin.

Truth and Reconciliation Commission of Canada. (2015a). Honouring the truth, reconciling for the future: Summary of the Final Report of the Truth and Reconciliation Commission of Canada. Winnipeg, MB: Author. Retrieved from http://www.trc.ca/websites/trcinstitution/File/2015/Findings/Exec_Summary_2015_05_31_web_o.pdf

Truth and Reconciliation Commission of Canada. (2015b). The survivors speak. A report of the Truth and Reconciliation Commission of Canada. Winnipeg, MB: Author. Retrieved from http://www.trc.ca/websites/trcinstitution/File/2015/Findings/Suvivors_Speak_2015_05_30_web_o.pdf

Tuck, E. (2009). Suspending damage: A letter to communities. Harvard Educational Review, 79(3), 409-428. Retrieved from

http://myaccess.library.utoronto.ca/login?url=https://search-proquest-com.myaccess.library.utoronto.ca/docview/61 828154? accountid $=14771$

Tuck, E., \& Gorlewski, J. (2016). Racist ordering, settler colonialism, and edTPA: A participatory policy analysis. Educational Policy, 30(1), 197-217. https://doi.org/10.1177/0895904815616483

Tuck, E., \& Ree, C. (2013). A glossary of haunting. In S. H. Jones, T. E. Adams, \& C. Ellis (Eds.), Handbook of autoethnography (pp. 639-658). Walnut Creek, CA: Left Coast Press, Inc.

Tuck, E., \& Yang, K. W. (2014). Youth resistance research and theories of change. New York: Routledge. 
Tupper, J. A. (2014). The possibilities for reconciliation through difficult dialogues: Treaty education as peacebuilding. Curriculum Inquiry, 44(4), 469-488. https://doi.org/10.1111/curi.12060

Tupper, K. W. (2011). Ayahuasca, entheogenic education \& public policy (T). Vancouver: University of British Columbia. Retrieved from https://open.library.ubc.ca/cIRcle/collections/24/items/1.0064622

Vizenor, G. (2008), Survivance: Narratives of indigenous presence. Lincoln, NE: University of Nebraska Press,

Williams, H. M. A. (2017). Teachers' nascent praxes of care: potentially decolonizing approaches to school violence in $\begin{array}{llllll}\text { Trinidad. Journal of } & \text { Peace } & \text { Education, } & 14(1), & 1-23 .\end{array}$ http://dx.doi.org.myaccess.library.utoronto.ca/10.1080/17400201.2016.1245656

Wilson, S. (2013). Using indigenous research to shape our future. In M. Gray, J. Coates, M. Yellow Bird, \& T. Hetherington (Eds.), Decolonizing social work. Farnham, Surrey UK: Ashgate Publishing Ltd.

\section{Copyrights}

Copyright for this article is retained by the author(s), with first publication rights granted to the journal.

This is an open-access article distributed under the terms and conditions of the Creative Commons Attribution License which permits unrestricted use, distribution, and reproduction in any medium, provided the original work is properly cited. 